\title{
PHYSICAL TRAINING OF CANDIDATES TO PROFESSIONAL MILITARY SERVICE IN LITHUANIAN ARMED FORCES
}

\author{
Aurelijus Savonis, Algirdas Čepulènas \\ Lithuanian Academy of Physical Education, Kaunas, Lithuania
}

\begin{abstract}
Research back ground and hypothesis. There is a basic military training course (BMT) carried out in the Lithuanian Armed Forces. The aim of this course is to train soldiers for military service that they were able to perform individual tasks and acquire basic military preparation. There is a lack of research dealing with the effect of physical training programmes in military training courses on the changes in soldiers' physical fitness. We hypothesize that in the course of military training physical fitness of would-be soldiers improves.

Research aim was to analyse the structure and content of the BMT programme and the effect of its implementation on the changes in physical fitness for would-be soldiers.

Research methods: literature review, analysis of military physical training programmes, physical fitness testing.

Research results. During the first testing only $26.8 \%$ of would-be soldiers achieved the standards of physical fitness complex test, and during the second testing the standards of the complex test of physical fitness were achieved by $89.5 \%$ of service people. In the period of the course $\mathrm{VO}_{2} \max$ and Roufier index improved $(\mathrm{p}<0.001)$. Indices of physical fitness and functional capacity improved more in the first half of the course. At the end of the course the results of adapted military physical fitness of service people were worse compared to the results of their general physical fitness.

Discussion and conclusions. The program of general physical training was effective, but more attention should be paid to the improvement of adapted military physical fitness programme aiming at better results. During the basic military training course physical fitness and functional capacity of candidates improved and at the end of the course it reached the normative level of physical fitness.
\end{abstract}

Keywords: physical fitness, adapted military physical fitness, basic military course, testing.

\section{INTRODUCTION}

$\mathrm{M}$ ilitary service requires good health and physical fitness for soldiers. Professional military service admits persons who meet the health requirements and who have fulfilled the established physical fitness standards. There is a_basic military training course (BMT) carried out in the Lithuanian Armed Forces. The aim of this course is to train soldiers for military service that they were able to perform individual tasks and acquire basic military preparation. The duration of the course is 12 weeks. The programme of the course has been developed on the basis of the Order of the Minister of National Defence of the Republic of Lithuania of 2008-07-28 No. 715, the Order of the Commander of the Lithuanian Armed Forces of 2006-09-01 No.V-1137 and the Order of 2011-0520 No.V-505.

Physical training is one of main structural parts of soldiers' combatant training (Greičius et al., 1998; Skrebė, 2000; Lietuvos gynybos politikos 
baltoji knyga, 2002).The analysis of physical fitness of various army troop soldiers' is a focus of many scientific studies (Radžiukynas, 1999; Sokołowski, 2002; Górski, 2007; Witkowski et al., 2007; Dobosz, Świercz, 2011). Only a minority of the scientific studies analyse the problems related to physical training of the Lithuanian professional soldiers and the peculiarities of physical fitness turn over of soldiers who represent different age groups during their time of service (Vilkas et al., 1994); Čepulènas, Klenauskas, 2002; Ivaškiene, 2003; Trinkūnas, 2009). Physical fitness and the peculiarities of its changes during the BMT course among the volunteering candidates for professional military services in Lithuania have received inadequate attention in research literature. The aim of the research was to analyse the structure and the content of the BMT programme and the effect of its implementation on the changes in physical fitness for would-be soldiers.

\section{RESEARCH METHODS}

The research sample included 250 persons who participated in BMT course in 2011. BMT course was carried out in the Training Regimen of the Lithuanian Great Hetman Jonušas Radvila. Physical fitness was assessed using the following tests: bending and reaching arms in a lying position for $2 \mathrm{~min}$ (times), test for abdominal muscle strength on the Sit-ups for 2 min (times); endurance test $-3000 \mathrm{~m}$ run (min, s). Functional capacity was assessed by the indices of Roufier test and maximal oxygen consumption $\left(\mathrm{VO}_{2} \max \right)$ which was established indirectly, performing a step test (Kariu fizinio rengimo metodines rekomendacijos, 2003). The testing was carried out at the beginning (testing 1), in the middle (testing 2) and at the end of BMT programme (testing 3). Eight control tests were performed: $8 \mathrm{~km}$ military march with $10 \mathrm{~kg}$ outfit: military obstacle course, grenade throw standing up, lying down, kneeling, and speeding up, military self-defence first-level test, swimming and overcoming obstacles in the water. Physical fitness results in each exercise were evaluated in points using the differentiated scale of evaluation according to age and gender (Table). At the end of BMT course would-be soldiers had to collect no less than 60 points in each test. The data were processed applying statistical programme SPSS 12. for Windows. We calculated arithmetic means $(\bar{x})$, standard deviation $( \pm \mathrm{SD})$, Student $(\mathrm{t})$ test criterion, and index $\mathrm{p}$ for statistical significance. The level of significance was set at $95 \%$ when $\mathrm{p}<0.05$.

\section{RESEARCH RESULTS}

The whole BMT course includes 645 hours. BMT physical training programme had 120 hours. According to the number of hours for each subject, physical training occupied the second position after tactical preparation, which had 248 hours. Physical training course included physical training theory $(2 \%)$, general physical training (42\%), and applied military physical training (56\%). General physical training included learning correct performance of physical exercises (4\%), strength development (23\%), endurance development (25\%), flexibility development $18 \%$ ); speed and agility development (6\%), testing physical skills (24\%). Applied military physical training programme included technical training of overcoming military section obstacles $13 \%$ ), preparation for a military march $(6 \%)$, training military combat self-defence actions $(41 \%)$, training combat grenade throws $(7 \%)$, training military swimming $12 \%$ ), applied military physical training testing $(21 \%)$.

During the first physical fitness testing (Figure 1) only $26.8 \%$ of would-be soldiers met the standards of all three control tests (each exercise was evaluated in no less than 60 points). The testing showed that would-be soldiers had weak abdominal muscles as the average point in sit ups exercise was 56.1 points (Figure 2).

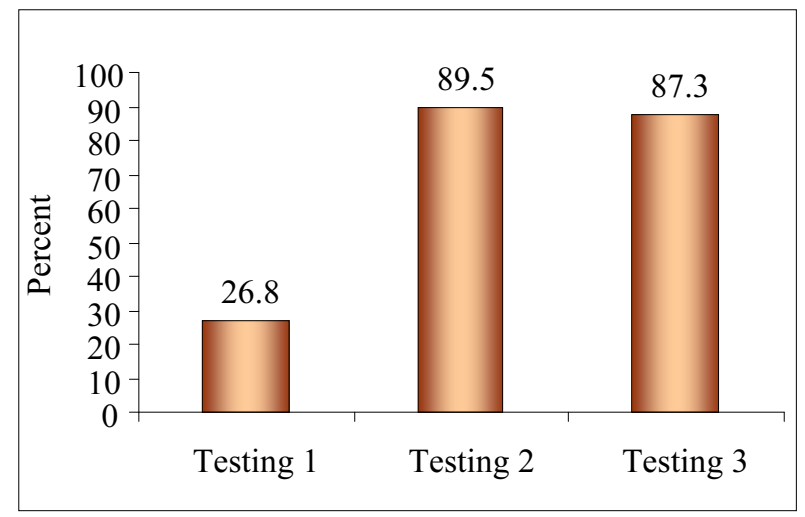

Figure 1. Changes (percentage) in the performance of general physical fitness complex test standards during the BMT course 


\begin{tabular}{|c|c|c|c|c|c|c|c|}
\hline \multirow[b]{2}{*}{ No } & \multirow{2}{*}{$\begin{array}{c}\text { Age } \\
\text { group }\end{array}$} & \multicolumn{2}{|c|}{$\begin{array}{l}\text { Bending and reaching arms in a } \\
\text { lying position } 2 \text { min, times }\end{array}$} & \multicolumn{2}{|c|}{ Sit-ups 2 min, times } & \multicolumn{2}{|c|}{$3000 \mathrm{~m}$ run, $\mathrm{s}$} \\
\hline & & $\begin{array}{c}\text { Those who } \\
\text { scored } 60 \\
\text { points }\end{array}$ & $\begin{array}{c}\text { Those who } \\
\text { scored } 100 \\
\text { points }\end{array}$ & $\begin{array}{c}\text { Those who } \\
\text { scored } 60 \\
\text { points }\end{array}$ & $\begin{array}{c}\text { Those who } \\
\text { scored } 100 \\
\text { points }\end{array}$ & $\begin{array}{c}\text { Those who } \\
\text { scored } 60 \\
\text { points }\end{array}$ & $\begin{array}{c}\text { Those who } \\
\text { scored } 100 \\
\text { points }\end{array}$ \\
\hline 1 & $18-21$ & 42 & 71 & 53 & 78 & $15: 00$ & $12: 06$ \\
\hline 2 & $22-26$ & 40 & 75 & 50 & 80 & $15: 42$ & $12: 06$ \\
\hline 3 & $27-31$ & 39 & 77 & 45 & 82 & $16: 06$ & $12: 24$ \\
\hline 4 & $32-36$ & 36 & 75 & 42 & 76 & $16: 48$ & $12: 24$ \\
\hline 5 & $37-41$ & 34 & 73 & 38 & 76 & $17: 24$ & $12: 42$ \\
\hline 6 & $42-46$ & 30 & 66 & 32 & 72 & $17: 48$ & $13: 12$ \\
\hline 7 & $47-51$ & 25 & 59 & 30 & 66 & $18: 36$ & $13: 30$ \\
\hline
\end{tabular}

Table. Physical fitness test scores in different age groups

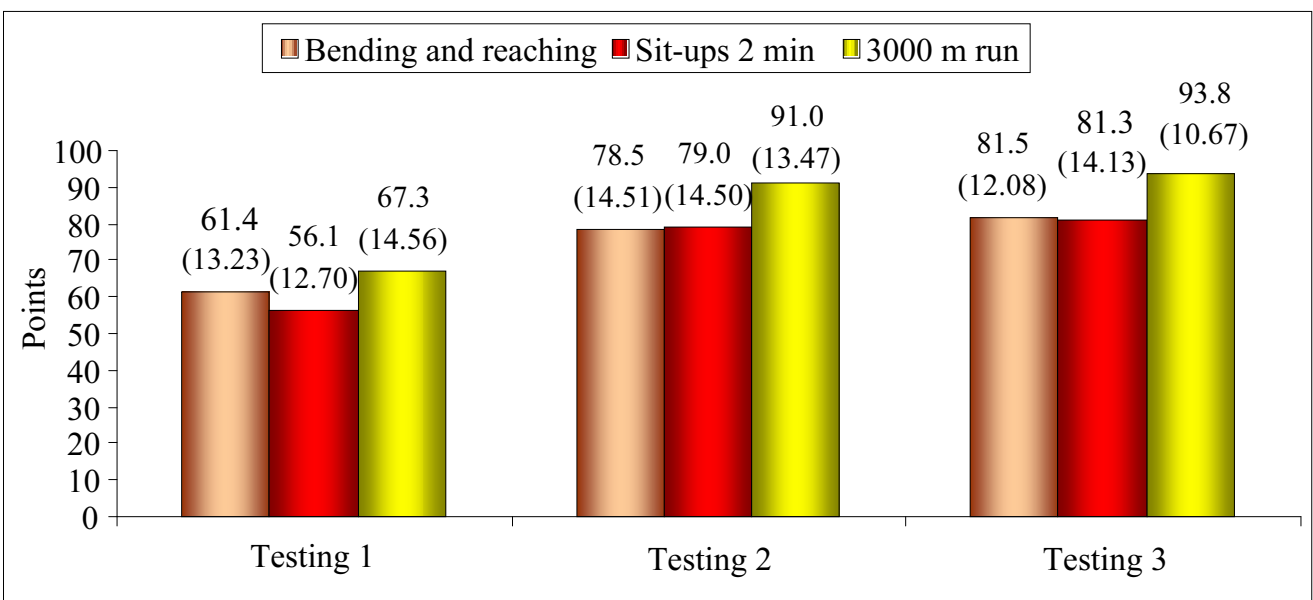

Figure 2. Changes in general physical fitness of soldiers during the BMT course according to points $(\bar{x} \pm$ SD) for each exercise

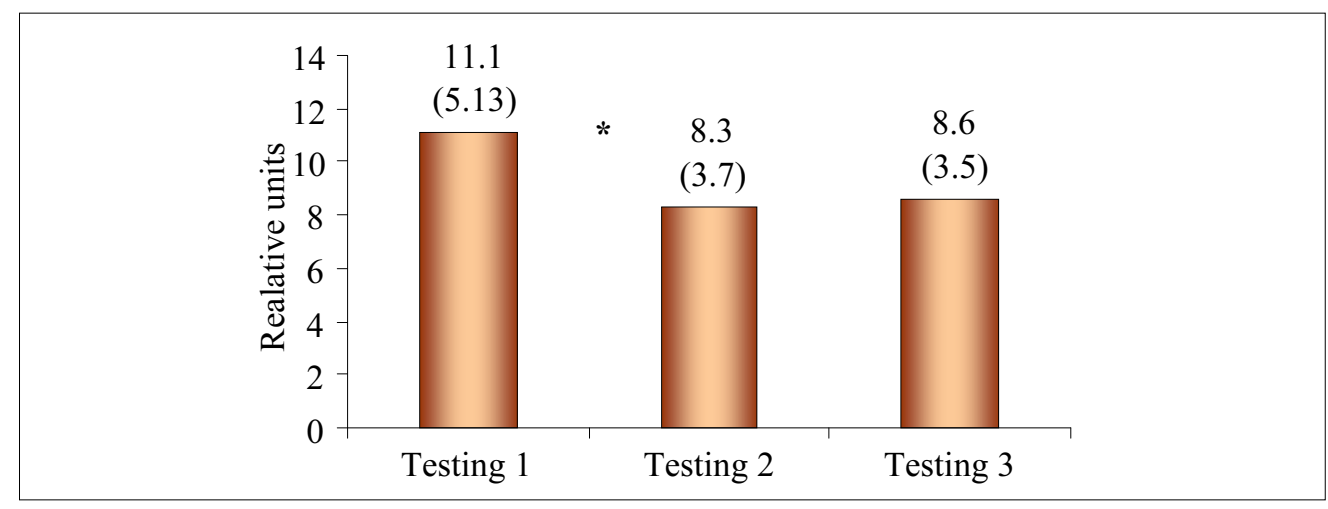

Figure 3. Changes in the indices of Roufier test $(\bar{x} \pm$ SD) during the BMT course

Note. ${ }^{*}-\mathrm{p}<0.001$

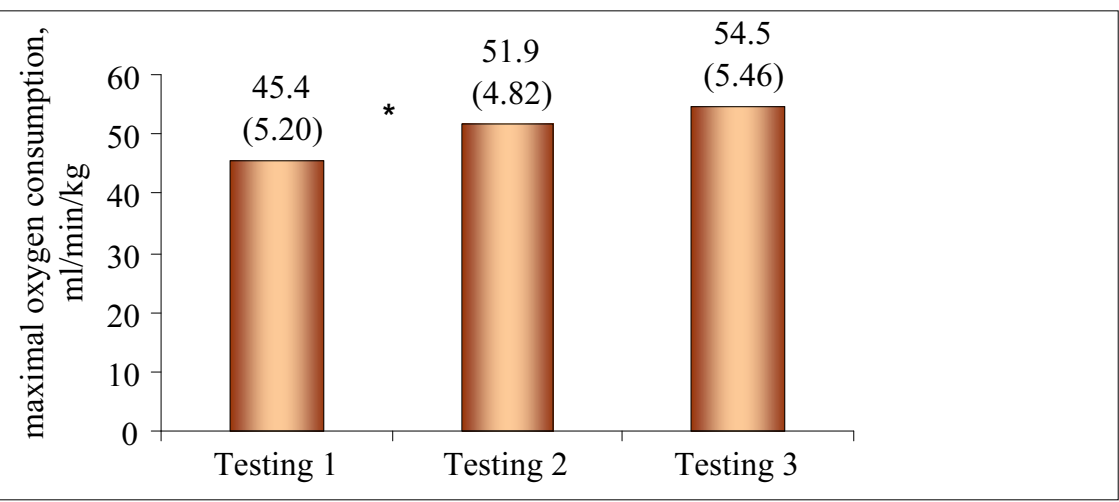

Figure 4. Changes in maximal oxygen consumption indices $(\bar{x} \pm \mathrm{SD})$ of soldiers during the BMT course

Note. ${ }^{*}-\mathrm{p}<0.001$. 
Figure 5. Results of the performance of adapted military physical fitness standards in percent

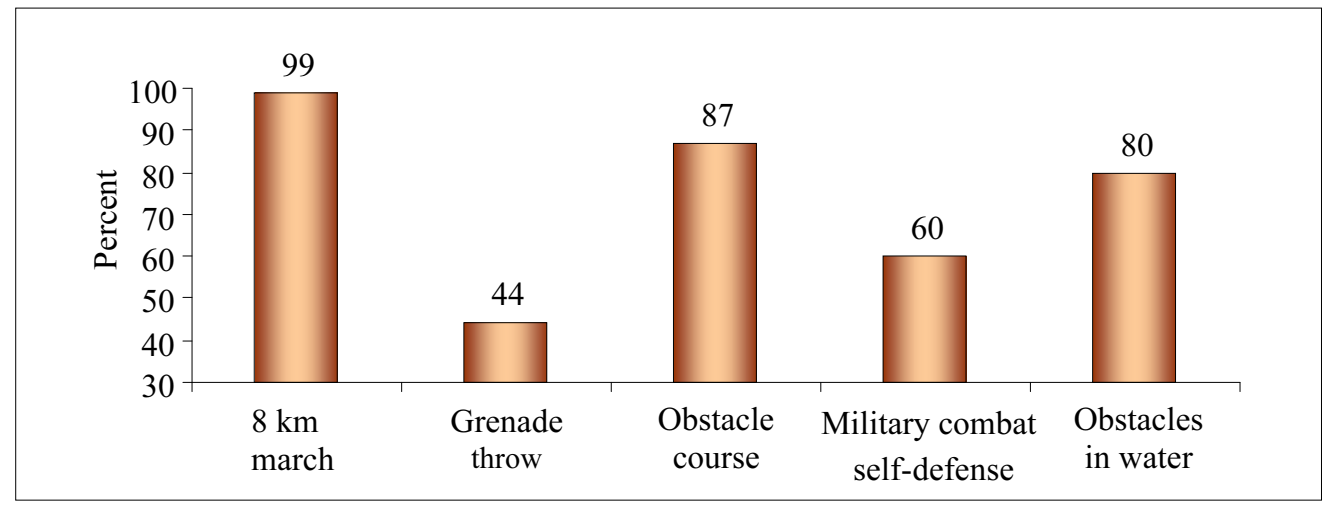

The points were awarded according to the subject's age following evaluation scale. During the tests they decreased to $87.8 \%$. It can be explained by the fact that at the end of BMT programme the candidates were tired as their physical loads increased due to testing in the applied military physical training. Candidates to professional military service demonstrated low indices (Figure 3,4 ) of functional body capacity (poor Roufier test and $\mathrm{VO}_{2}$ max indices).

The results of applied military physical training testing (Figure 5) at the end of BMT programme were as follows: $98.5 \%$ of candidates carried out $8 \mathrm{~km}$ military march meeting the norms, $43 \%$ grenade throws, $87.3 \%$ - overcoming military section obstacles, $60.5 \%$ - military combat selfdefence, $79.8 \%$ - swimming and overcoming obstacles in the water.

\section{DISCUSSION}

It is relevant to carry out tests of soldiers' physical fitness as well as optimize their physical training programs in accordance with the obtained results. The first testing of would-be soldiers showed that their physical fitness did not correspond to the levels required for soldiers in professional military service. The capacity of the cardiovascular system of would-be soldiers was evaluated by the indices of $\mathrm{VO}_{2} \mathrm{max}$ and Roufier test. At the beginning of the course the $\mathrm{VO}_{2} \max$ indices $(\bar{x})$ of service people amounted to $45.4 \pm 5.20 \mathrm{ml} / \mathrm{min} / \mathrm{kg}$, and Roufier test index was $11.1 \pm 5.13$ relative units. These indices showed satisfactory and poor level (Kariu fizinio rengimo metodinès rekomendacijos, 2003).

Lack of physical activity is characteristic of today's schoolchildren, especially at the age of
17-18, and this directly impacts physical fitness results of young men of military age (Greičius et al., 1998). Suitability for military service is determined not only by the person's health, but also the indices of physical fitness and physical capacity (Radžiukynas, 1999; Skrebė, 2000).

During the second testing, which took place in the middle of the course, the subjects showed improved physical fitness results. The standards of the complex test of physical fitness were achieved by $89.5 \%$ of service people. Flexibility improved most; its average point in $3000 \mathrm{~m}$ running was 91.0. Hand grip strength and abdominal muscle power increased as well and it amounted to 78.5 and 79.0 points (Figure 2). We should note that the improvement in the indices of physical fitness was greater in the first half of the course. If we compare the results of the second and the third testing, we will notice that the improvement was not so expressed. In the period of the course the $\mathrm{VO}_{2} \max$ indices improved from $45.4 \pm 5.20 \mathrm{ml} / \mathrm{min} / \mathrm{kg}$ to $54.5 \pm 5.46 \mathrm{ml} / \mathrm{min} / \mathrm{kg}(\mathrm{p}<0.001)$, and Roufier index improved from $11.1 \pm 5.13$ to $8.6 \pm 3.5$ relative units $(p<0.001)$. Indices of functional capacity improved more in the first half of the course.

Some authors (Trinkūnas, 2009) suggest that physical fitness is better of persons called to the Army who are from villages, and not from the cities, but during BMT course persons improve their physical fitness more.

Testing of adapted military physical fitness at the end of the course showed (Figure 5) that the level of adapted military physical fitness of service people was lower compared to the standard requirements. As many as 53\% of subjects failed in grenade throw test, $38.8 \%$ - in military selfdefence, $10.5 \%$ did not overcome obstacle course, and $17.2 \%$ failed in overcoming obstacles in water. 
The performance of adapted military physical fitness tasks requires learning new complex movements and psychological stability in performing them (Skrebe, 2001). The formation and consolidation of technical skills require more time. The performance of adapted military physical fitness tasks is greatly affected by psychological stress due to difficult conditions of performance (Scahafer, 1992; Cox, 1994). Psychological tension is expressed in inability to control one's actions (Masiulis, 2006). We suppose that due to those factors the results of adapted military physical fitness of service people were worse compared to the results of their general physical fitness.

At the end of the course the results of adapted military physical fitness of service people were worse compared to the results of their general physical fitness. Some persons failed in achieving the standards of adapted military physical fitness.

\section{CONCLUSIONS AND PERSPECTIVES}

The programme of general physical training was effective, but more attention should be paid to the improvement of adapted military physical fitness programme aiming at better results.

During the basic military training course physical fitness of candidates improved and at the end of the course it reached the normative level of physical fitness. The majority of would be soldiers are still unable to meet some of the normative requirements of the applied military physical training.

\section{REFERENCES}

Cox, R. H. (1994). Sport Psychology. Concepts and Applications. Dubuque: Brown \& Benchmark.

Čepulènas, A., Klenauskas, S. (2002). Change of soldiers physical preparedness during servise period. Kultura fizyczna $w$ wojsku $w$ dobie przemiar. Pod redakcja M. Sokołowskiego (pp. 23-27). Wydawnictwo Wyzszej Szkoły oficierskiej im. Stefana Czarnieckiego. Poznań.

Dobosz, J., Świercz, M. (2011). Physical fitness of soldiers from land forces units in 2009 and 2010 years. In A Diagnosis of Physical Fitness in the Contemporary Army (pp. 39-61). Warszawa: Polish Scientific physical education association section of physical education in the army.

Górski, P. (2007). Compensatory training programs for regular cadre of the Polish army. In M. Sokołowski (Ed.), Biosocial Effects of Military Service as a Basis for Further Improvement of Future Physical Education and Sports Programmes (pp. 277-284). Poznań Akademia Wychowania fizyczniego im. Piaseckiego w Poznaniu.

Greičius, R., Tutkus, E., Skrebė, B., Kočiubaitis, V. (1998). Lietuvos kariuomenes kariu fizinis rengimas [CD-ROM]. Vilnius.

Ivaškienè, V. (2003). The development of physical preparedness of soldiers. In M. Sokołowski (Ed.), Biospoleczne aspekty kultury fizycznej w wojsku (pp. 114-121). Poznań: AWF.

Kariu fizinio rengimo metodinès rekomendacijos. (2003). Parengė R. Greičius, E. Tutkus, V. Kočiubaitis. Kaunas: Karo medicinos tarnyba.

Lietuvos gynybos politikos baltoji knyga. (2002). Vilnius: Lietuvos Respublikos krašto apsaugos ministerija.

Masiulis, N. (2006). Fizinio aktyvumo poveikis stresui, nerimui ir depresijai mažinti. Šiuolaikinių technologijų analizè. A. Skurvydas ir kt., Fizinis aktyvumas ir sveikata (pp. 99-116). Kaunas: Lietuvos kūno kultūros akademija.

Radžiukynas, D. (1999). Lietuvos karo akademijos kariūnu fizinis ugdymas pirmais studiju metais: daktaro disertacija. Vilnius: Vilniaus pedagoginis universitetas.

Schafer, W. (1992). Stress Management for Wellness. New York: Harcourt Brace Jovanovich.

Skrebė, B. (2000). Kariu fizinis rengimas. Vilnius.

Skrebè, B. (2001). Kliūčiu ruožo j̇veikimo metodika. Vilnius.

Sokolowski, M. (2002). Wychowanie fizyczne i sport w procesie prsygotowania Zawodowego w wojsku. M. Sokolowski (Ed.), Kultura fizyczna $w$ wojsku $w$ dobie przemian (pp. 324-328). Wydawnictwo Wyzszej Szkoly Oficierskiej im. Stefana Czarnieckiego. Poznań.

Trinkūnas, E. (2009). Skirtingo šaukimo karių fizinio pasirengimo kaita bazinio kurso metu. Sportini darbinguma lemiantys veiksniai (II): moksliniu straipsniu rinkinys (el. versija) (pp. 164-173). Kaunas: Lietuvos kūno kultūros akademija.

Vilkas, A., Kepežènas, A., Radžiukynas, D. (1994). Lietuvos kariuomenès karių, pašauktų 1993 m. pavasarị, fizinio išsivystymo, fizinio parengimo ir organizmo funkciniu galimybiu tyrimo duomenys. Ivairaus amžiaus gyventoju fizinio ugdymo ir sveikatos problemos (pp. 119-122). Vilnius.

Witkowski, K., Stefaniak, T., Majsnerowski, M. (2007). Physical fitness of soldiers in the regular or professional military service in the NATO response task force. In M. Sokolowski (Ed.), Biosocial Effects of Military Service as a Basis for Further Improvement of Future Physical Education and Sports Programmes (pp. 145153). Poznań Akademia Wychowania fizyczniego im. Piaseckiego w Poznaniu. 


\title{
KANDIDATŲ I LIETUVOS KARIUOMENĖS PROFESINĘ KARO TARNYBĄ FIZINIS RENGIMAS
}

\author{
Aurelijus Savonis, Algirdas Čepulènas \\ Lithuanian Academy of Physical Education, Kaunas, Lithuania
}

\begin{abstract}
SANTRAUKA
Tyrimo pagrindimas ir hipotezė. Lietuvos kariuomenèje vykdomi baziniai kariniai mokymai (BKM), kuriu tikslas parengti profesinei karo tarnybai karius, gebančius atlikti nustatytas individualias užduotis ir igyti pagrindini karini parengtumą. Trūksta mokslinių tyrimų, nagrinëjančių bazinių karinių mokymų fizinio rengimo programos vykdymo poveikị karių fizinio pajëgumo kaitai. Keliama hipotezè, kad per bazinius karinius mokymus būsimujų karių fizinis pajègumas gerëja.

Tikslas - išanalizuoti BKM fizinio kariu rengimo programos struktūrą ir turini bei nustatyti jos vykdymo poveikị būsimų karių fizinio pajègumo kaitai.

Metodai: literatūros šaltinių studija, bazinių karinių mokymų fizinio rengimo programos analizé, fizinio parengtumo testavimas.

Rezultatai. Per pirmą testavimą tik $26,8 \%$ būsimujų karių ỉvykde bendrojo fizinio parengtumo kompleksinio testo normatyva, o per antrą ši normatyvą ivykdè 89,5\%. Per mokymų laikotarpi pagerejjo $(\mathrm{p}<0,001)$ maksimalaus deguonies suvartojimo ir Rufjè indekso rodikliai. Fizinio parengtumo ir funkcinio pajègumo rodikliu pagerẻjimas buvo didesnis per pirmą mokymų pusę. Baziniu karinių mokymų pabaigoje kursantų taikomojo karinio fizinio parengtumo rezultatai buvo prastesni negu bendrojo fizinio parengtumo.

Aptarimas ir išvados. Bendrojo fizinio rengimo programa buvo veiksminga, tačiau reikètu atkreipti dèmesi $\mathfrak{i}$ karinio taikomojo fizinio rengimo programos tobulinimą siekiant geresnių rezultatu.

Per bazinius karinius mokymus būsimujų karių fizinis parengtumas ir funkcinis pajëgumas pagerèjo ir jie pasiekè kursų pabaigai nustatytą fizinio parengtumo normatyvini lygi.
\end{abstract}

Raktažodžiai: fizinis parengtumas, taikomasis karinis fizinis parengtumas, baziniai kariniai mokymai, testavimas.

Gauta 2012 m. birželio 13 d.

Received on June 13, 2012

Priimta $2012 \mathrm{~m}$. rugsèjo $7 \mathrm{~d}$.

Accepted on September 7, 2012

Corresponding author Aurelijus Savonis

Lithuanian Academy of Physical Education

Sporto str. 6, LT-44221 Kaunas

Lithuania

Tel +370 69809329

E-mail aurelijus.savonis@gmail.com 